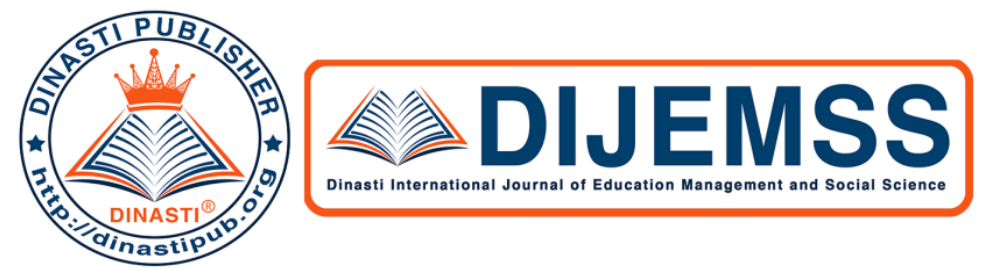

+6281387654578?

+6281387654578@

https://dinastipub.org/DIJEMSS (-) dinasti-info@gmail.com G.

\title{
MODEL OF ENTREPRENEURIAL MARKETING ON WOMENPRENEUR
}

\author{
Aldina Shiratina ${ }^{1}$, Yanto Ramli ${ }^{2}$, Nia Kusuma Wardhani ${ }^{3}$, Nandan Limakrisna ${ }^{4}$ \\ 1) 2) 3) Universitas Mercu Buana, Jakarta, Indonesia \\ 4) Universitas Persada Indonesia YAI, Jakarta, Indonesia
}

\begin{tabular}{|c|c|}
\hline $\begin{array}{l}\text { ARTICLE INFORMATION } \\
\quad \text { Received: } 01^{\text {st }} \text { April } 2020 \\
\quad \text { Revised: } 20^{\text {st }} \text { April } 2020 \\
\text { Issued: } 28^{\text {th }} \text { April } 2020 \\
\text { Corresponding author: } \\
\text { Aldina Shiratina } \\
\text { E-mail: } \\
\text { aldina.shiratina@mercubuana.ac.id } \\
\text { aldinashiratina@gmail.com }\end{array}$ & $\begin{array}{l}\text { Abstract: This research revealed the model of } \\
\text { entrepreneurial marketing, especially on Moslem fashion } \\
\text { womenpreneurs. Recently, the opportunity for women in } \\
\text { entrepreneurship with micro and small scale businesses } \\
\text { (MSMEs) has increase. Womenpreneur also contributes to } \\
\text { the field of human resource management, namely } \\
\text { empowering women and playing a role in the nation's } \\
\text { economy. The main reason is that they want to be } \\
\text { independent, followed by the second rank who says that } \\
\text { opening a business, especially the Moslem fashion } \\
\text { business, as an effort to increase family income. } \\
\text { Implementing the concept of entrepreneurial marketing } \\
\text { requires supporting factors, namely market orientation, } \\
\text { innovation, value creation, and risk-taking. The purpose of } \\
\text { this research is to implement the model of entrepreneurial } \\
\text { marketing on womenpreneurs. This research used a } \\
\text { descriptive survey method through SEM (Structural } \\
\text { Equation Models) analysis. Sample of this research is } 209 \\
\text { Moslem fashion womenpreneurs with a small business } \\
\text { scale in West Java from different characteristics, both shar'i } \\
\text { Moslem fashion (veiled), semi-shari'a and trendy. This } \\
\text { research has been reduced the dimensions of previous } \\
\text { studies, only focus on market orientation, innovation, and } \\
\text { value creation, without risk-taking factors because } \\
\text { womenpreneurs have been thinking first before they start } \\
\text { the business and they have calculated risk factors. that } \\
\text { value creation can be formed from market orientation and } \\
\text { innovation. As we can say, market orientation and } \\
\text { innovation are important factors in the formation of value } \\
\text { creation for women entrepreneurs of small scale Moslem } \\
\text { fashion in West Java By applying these concepts, it builds } \\
\text { an effective entrepreneurial marketing performance for } \\
\text { womenpreneur. }\end{array}$ \\
\hline
\end{tabular}


Keywords: Entrepreneurial Marketing, Innovation, Market Orientation, Value Creation, Womenpreneur

\section{INTRODUCTION}

The development of business in the MSME sector is currently increasingly stretched, with the role of women in the business world turns out increasingly visible. If once a woman could only remain in the house and take all of the household matters, now gender equality has provided a great opportunity for womenfolk to be able to score achievements in their fields.

The role of women in the economy is still limited because there is an assumption that women are only suitable to work as housewives. However, the contribution of women in the Indonesian economy is hindered by the stereotype that women must do domestic work while men work in technical and industrial fields. At present, the proportion of women in the company's top management is only five percent. Meanwhile, the majority of working women tend to be in the informal sector. Such conditions made women empowering have to face three major challenges, namely limited financial access, limited network and market access, and limited competence (Safyra, 2015).

The developed number of women who become business owners in recent years currently has increased. Womenpreneur needs to get attention from several agencies, both private and government. Women also have a big role in the economic progress of a country. Based on a recent study conducted by the Asia Foundation, it shows that around 23 percent are women entrepreneurs. The amount, growing 8 percent every year. In Indonesia alone, the number of women entrepreneurs is mostly in the micro and small scale. Data from the Ministry of Cooperatives and SMEs in 2015 recorded, of the approximately 52 million MSME actors in Indonesia, as many as 60 percent of businesses are run by women. This woman's MSME has survived the most monetary, economic, food and energy crises that have befallen the world and Indonesia in the last 10 years. Thus, a lot of support should be given to women to become entrepreneurs. Seeing the very large number of women entrepreneurs, it is therefore expected that the number can continue to increase. In order, they can play a significant role in economic development in Indonesia (Lia; 2015).

Womenpreneurs it is certain to find challenges, as for those challenges according to Das (2000) research, that only one-fifth of the womenpreneurs surveyed said that they opened their businesses because of "push" factors, such as the desire for a challenge, the need to try something yourself, the desire to be independent, and to show others that he is capable of running a business. The results showed that the main reason for a woman to open or do her own business was mostly because she wanted to be independent, followed by the second rank who said that opening a business as an effort to increase family income or help her husband. After all, his salary was insufficient besides that womenpreneur generally they were ready intake risks in running his business (Tambunan, 2012). The participation of women in various sectors is very high, following the advantages possessed by women such a diligent, conscientious, resilient, patient, honest, tough, high sense of responsibility, strong will, high spirits and discipline (Indiworo, 2017).

Womenpreneurs in developing countries seem to play an important role in the economy and development process through women empowerment in these countries (De Vita, et al; 2013). If related to the growth of MSMEs (Micro, Small and Medium Enterprises) in the field of Moslem fashion, generally womenpreneurs from 2010-2015, especially in 2015 which has 
indeed declined, this is allegedly the findings of funding a national and global economic slowdown but the West Java Provincial Government through West Java KUKM Office will continue to strive for better quality cooperatives, both through policies to improve cooperatives and other institutions and businesses (Dinas KUKM West Java Province, 2016). This is alleged that the quality of Moslem fashion products in West Java is still not good. The quality of Moslem entrepreneurs can be seen from their business performance which is also triggered by the existence of entrepreneurial marketing performance which can be formed, one of which is the market orientation (Sole; 2013). Furthermore, Morris, et al, (2002; 5) put forward the definition of entrepreneurial marketing that can be abbreviated, namely EM. EM is an opportunity to proactively identify and exploit to obtain and retain profitable customers through innovative approaches to risk management, resource leveraging and value creation.

Moslem fashion entrepreneurs here dominate the most, according to Harry Ibrahim, as the Chairperson of the West Java branch of APPMI when interviewed at a press conference at the Estructura event, saying, "Moslem fashion for West Java feels the strongest for all of Indonesia. Proven Moslem fashion designers in Indonesia many in West Java and hijabs in West Java have strong communities, "(Banjarmasin Post, September 2014). Moslem fashion entrepreneurs in West Java are the most numerous, but these entrepreneurs in creating value or creating value in creating a clothing design for consumers are allegedly still inadequate.

Value creation can be formed if business actors, especially MSMEs often innovate their products, this is following the research of Alshammari et al (2014), it was revealed that the underlying competitive advantage is the need to increase the ability of small companies to create uniqueness and need to apply the concept of learning culture to be a driver to get high added value in value creation and organizational innovation. In addition to innovation, there are market orientation factors that can support entrepreneurs in creating value for customers, this is following research revealed by Chung (2014), that market-oriented companies have a positive impact on the ability to create customer value significantly.

The purpose of this paper is to build an entrepreneurial marketing model for women entrepreneurs by looking at the relationship between market orientation, innovation, and value creation, which can be divided into 1) influence between market orientation and innovation, 2) influence between market orientation and value creation, and 3) influence between innovation and value creation.

\section{LITERATURE REVIEW \\ Entrepreneurial Marketing}

In 1987 a statement began to appear "marketing is a container in the entrepreneurial process" (Morris and Paul; 1987; 247). Bjerke and Hultman (2002: 15) also in his book revealed that "EM is a marketing in a small company that can grow through entrepreneurship".

Morris, et al, (2002; 5) The definition of entrepreneurial marketing that can be abbreviated as EM. "EM is an opportunity for proactive identification and exploitation in obtaining and retaining profitable customers through a risk management, resource utilization, and value creation approach". In 2004 the EM definition emerged of a composition consisting of a proactive organizational focus on customer satisfaction through innovative and efficient value creation throughout the value chain (Miles and Darroch, 2004).

Becherer et al (2008) revealed that entrepreneurial marketing is a marketing process of companies that pursue opportunities in uncertain market situations. Definition according to Hills, 
et al $(2010 ; 6)$ "EM is spirit, orientation as well as a process of pursuing opportunities and launching, and growing ventures that create perceived customer value through relationships, especially by employing innovativeness, creativity, selling, market immersion, networking, or flexibility".

Kraus, et al (2010: 26) combine marketing definitions according to AMA (American Marketing Association) with the understanding of entrepreneurship as follows "EM is an organizational function and a set of processes for creating, communicating and delivering value to customers and for managing customer relationships in ways that benefit the organization and its stakeholders, and that is characterized by innovativeness, risk-taking, pro-activeness, and may be performed without resources currently controlled".

Jones and Rowley (2011) were concluded that entrepreneurial marketing is a strategic direction by involving members in organizational practice to integrate customer preferences, competitor intelligence, and product knowledge through the process of creating and providing more value to customers. According to Hills and Hultman (2011) revealed that Entrepreneurial marketing is something that is considered more proactive, more innovative, more opportunities and growth-oriented, and more willing to take risks than conventional markets. Hacioglu et al, (2012) argue that entrepreneurial marketing is a process that is accompanied by an entrepreneurial spirit (marketing by founder-entrepreneur). Then according to Daniela IONIŢĂ, $(2012 ; 147)$ "EM is a set of processes of creating, communicating and delivering value, guided by effectual logic and used a highly uncertain business environment".

Based on the definition of Entrepreneurial Marketing (EM), it can be revealed that EM is an organizational function in which there is a process that is more focused in capturing market opportunities to gain and retain profitable customers by creating value and establishing relationships with customers, then creativity is also needed and innovative and have preparedness in facing business risks.

In this research, the focus will be on entrepreneurial marketing in building women's empowerment in developing their businesses that have creativity, and innovation to make things better, to be more competitive with the skills used in the fashion Moslem field and to be able to motivate themselves in improving their business (Karwati, et al; 2018). So the factors that are focused on are market orientation, innovation, and value creation, without using risk management, this is because generally, womenpreneurs have considered these factors in running their business.

\section{Market Orientation}

An entrepreneur needs to implement the right market orientation by applying the right concepts. Successful entrepreneurship can be seen from the side of how an entrepreneur can see market opportunities and our tenacity in doing business (Becherer et al, 2006), Jones and Rowley (2011) reveal that market orientation is a concept formed as part of Entrepreneurial Marketing applied in small businesses. this can apply market orientation in entrepreneurship. market orientation in entrepreneurship that can be said to be entrepreneurial.

Narver and Slater (1990) revealed the original definition of market orientation as an organizational culture that most effectively and efficiently created the behaviors needed to create super buyer value and thus superior performance for business. Li, et al (2008) revealed that market orientation is a behavior that focuses on customer expectations and changes in market competition in achieving optimal performance in small businesses. Jiménez-Zarco, et al (2008) 
revealed that market orientation is a principle that results in a new orientation towards the company's relationship with customers and a focus on creating and maintaining these relationships. So the purpose of this conceptual orientation is a concept in running a business with a focus on customers, oriented to competitors and the interaction in the company.

\section{Innovation}

The concept of innovation from several previous researchers, according to Kemp, et al (2003), revealed that innovation is a process of renewal from input to competitor to output so that it will produce a performance. However, Wang and Ahmed (2004) further discussed that innovation in an organization is the overall innovative ability of a company to introduce new products to the market, or open new markets, by combining strategic orientation with innovative behavior and processes. Furthermore, the OECD Oslo Manual (2005) reveals that innovation is the implementation of significant changes to products (both goods or services), or new processes, marketing methods, or new organizational methods in business practices, workplace organizations or external relations. Furthermore, Kotler and Keller $(2016 ; 611)$ also revealed their definition that "Innovation is a product, service or idea that some people perceive as something new no matter how long its history is". So the intended innovation in this concept is a renewal idea whether it is a product, process, or marketing method.

\section{Value Creation}

Value creation also could be applied to e-business as revealed in conceptual research according to Amit \& Zott (2001) value creation is a potential in implementing e-business that depends on novelty, locking, complementary and efficiency. Peter, Linda. D (1997) revealed in his research that value creation is an activity by utilizing the effectiveness of IT in marketing including products and services that will create customer value in the long run, and competitive advantage. Furthermore, Johansson and Mollstedt (2006) revealed in their research that value creation is a process of creating a strong relationship between suppliers and customers and stakeholders in providing benefits through e-business services. Grönroos (2011), also made the concept that in supporting value creation in the process of corporate engagement with customers is a mutually beneficial marketing goal. However, Cravens \& Piercy (2014) revealed that the concept of value creation is a process within CRM by providing benefits that include product performance that can meet customer needs and total costs. Then the value creation in this study is a process in which there is a novelty by providing benefits to customers, maintaining good relationships with customers, and can make products that have their characteristics.

\section{Entrepreneurial Marketing Concept Relationship Between Market Orientation and Innovation}

The relationship between market orientation and innovation can be revealed that innovation can occur if the company is market-oriented as revealed by Rosmayani's research, et al (2016) revealed in his research that market orientation can affect marketing performance through innovation. In this case, we can illustrate that market orientation is indeed related to innovation.

Furthermore, Zainul, Astuti, Arifin, and Utami (2016) revealed in their research that market orientation can directly influence innovation, in other words, market orientation can 
encourage every company to innovate because only if supported by complete market information can innovation run well.

\section{Relationship Between Market Orientation and Value Creation}

Value creation could be formed from market orientation while research that shows the relationship between market orientation and value creation is a research model that brings companies to grow from starting to focus on market orientation which will later produce value in companies where there is an element of competitive advantage to produce satisfaction for customers to make loyal customers (McNaughton et al, 2002). Besides Mauludin et al, (2013), revealed the results of his research that market orientation is an activity that has become a culture in an organization that will be very effective and efficient to create products that have superior value for customers.

\section{Relationship Between Innovation and Value Creation}

Research on the relationship between innovation and value creation could be explained the innovation in generally would have a direct impact on the performance of a business, as in the research of Haryanto and Haryono (2015), which revealed that there is a positive relationship between market orientation and innovation in achieving company performance. But this is different when referring to the research of O 'Cass and Sok (2012), which revealed in his research that the capability of innovation has a positive impact or influence in conveying value to customers.

Based on the relationship between market orientation, innovation and value creation in shaping entrepreneurial marketing especially in Moslem fashions, it will produce a model that can be seen as follows:

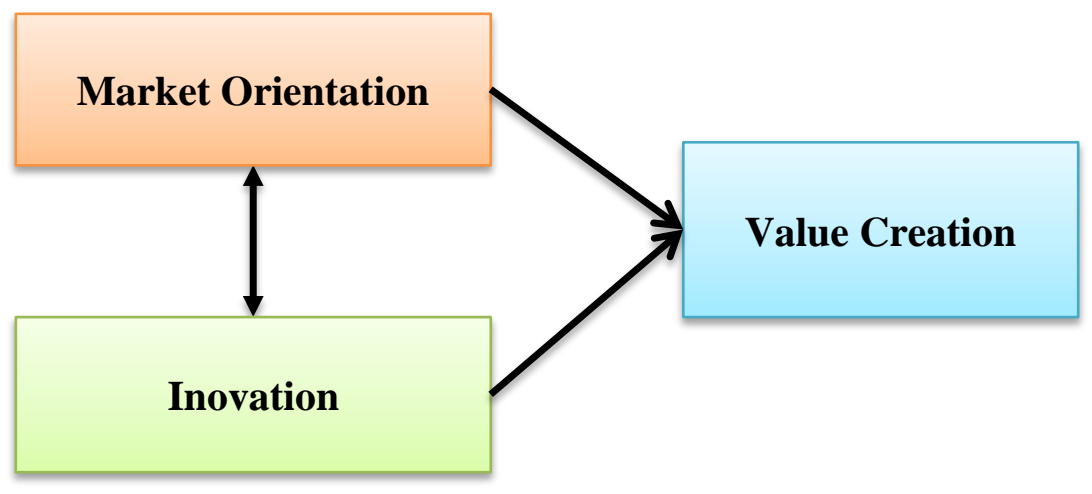

Figure 1. Conceptual Framework Of Entrepreneurial Marketing Model

\section{RESEARCH METHODS}

This research used quantitative method by using a descriptive survey and verification approach through SEM (Structure Equation Model). The research was conducted in West Java Province and has 209 Moslem fashion womenpreneur based on different characteristics, from the syar'i Moslem fashion (veiled), semi syar'i to the trendy, but Moslem fashion womenpreneur who produce and market Moslem clothing. This research uses a purposive sampling method with a questionnaire provided to Moslem fashion womenpreneurs. 
This research also uses an assessment to describe the results of a descriptive survey that can be seen in the following table:

Table 1. The Category of Moslem Fashion Womenpreneur

\begin{tabular}{|c|c|c|c|c|}
\hline \multirow{2}{*}{ No } & $\begin{array}{c}\text { Average } \\
\text { Interval Score }\end{array}$ & $\begin{array}{c}\text { Market } \\
\text { Orientation }\end{array}$ & Category \\
\cline { 3 - 5 } & $1,00-1,80$ & Very not oriented & $\begin{array}{c}\text { Very not } \\
\text { Innovative }\end{array}$ & Very not Creative \\
\hline 1 & $1,81-2,60$ & Not oriented & Not Innovative & Not Creative \\
\hline 2 & $2.61-3.40$ & Less oriented & Less Innovative & Less Creative \\
\hline 4 & $3.41-4.20$ & Oriented & Not Innovative & Creative \\
\hline 5 & $4.21-5.00$ & Very Oriented & Very Innovative & Very Creative \\
\hline
\end{tabular}

Source: Modication from J.Supranto and Nandan Limakrisna 2016.

\section{FINDINGS AND DISCUSSION}

Market orientation of Moslem fashion women entrepreneurs in West Java Province is derived through three dimensions, namely from customer orientation, competitor orientation, and coordination between functions. then for innovation, there are three dimensions, namely Product Innovation, Process Innovation, and Marketing Innovation. Furthermore, value creation consists of three dimensions, namely Customer Benefits, Business Uniqueness, and Business Partnership, which can be seen in the response table from the Moslem Fashion Womenpreneur.

Table 2. Moslem Fashion Womenpreneur Responses

\begin{tabular}{|c|l|c|c|}
\hline Variable & \multicolumn{1}{|c|}{ Dimension } & Avarages & Criteria \\
\hline \multirow{4}{*}{ Market Orientation } & 1. Customer Orientation & 3,69 & Oriented \\
\cline { 2 - 4 } & 2. Competitor Orientation & 3,32 & Less oriented \\
\cline { 2 - 4 } & $\begin{array}{l}\text { 3. Interfunctional } \\
\text { Coordination }\end{array}$ & 3,68 & Oriented \\
\hline \multirow{3}{*}{ Innovation } & 1. Product Innovation & 3,68 & Innovative \\
\cline { 2 - 4 } & 2. Process Innovation & 3,41 & Innovative \\
\cline { 2 - 4 } & 3. Marketing Innovation & 3,40 & Cess Innovative \\
\hline \multirow{3}{*}{ Value Creation } & 1. Customer Benefits & 3,80 & Creative \\
\cline { 2 - 4 } & 2. Business Uniqueness & 3,47 & Creative \\
\cline { 2 - 4 } & 3. Business Partnership & 3,46 & \\
\hline
\end{tabular}

Source: data was processed, 2019

In table 2, it appears that the results of descriptive research from responses according to Moslem fashion women entrepreneurs in West Java tend to highlight the value creation of their products and they are more likely to be creative, but in terms of innovative, there are marketing innovation factors that are still less innovation, whereas in a management company innovation is an important factor that can create uniqueness (Ramli and Soelton, 2018). Furthermore, in terms of market orientation, they tend to be less oriented towards competitors, this is possible because they are still not observant in seeing the strategies carried out by competitors. Furthermore, the following can be revealed regarding verification analysis, the influence of market orientation on value creation and innovation on value creation. 


\section{Market orientation affects partially value creation}

The effect of market orientation on value creation can be seen in the results described in table 3 below :

Table 3 Market orientation affects partially value creation

\begin{tabular}{|c|c|c|c|c|c|}
\hline Hypothesis & $\gamma$ & $\mathbf{S E}(\gamma)$ & $\mathbf{t}_{\text {count }}$ & $\mathbf{R}^{2}$ & Conclusion \\
\hline $\begin{array}{c}\text { Market Orientation } \rightarrow \\
\text { Value Creation }\end{array}$ & 0.39 & 0.071 & $5.68^{*}$ & 0.22 & $\begin{array}{c}\text { Hypothesis } \\
\text { Accepted }\end{array}$ \\
\hline
\end{tabular}

* significant at $\alpha=0.05(\mathrm{t}$ table $=1.96)$

Source: data was processed, 2019

In table 3 above it is known that the market orientation variable has a significant influence on value creation, where $t_{\text {count }}>t_{\text {table }}$ with a coefficient of determination $R 2$ of $22 \%$. It can be said that $\mathrm{H}_{0}$ was rejected and $\mathrm{H} 1$ is accepted. For more details can be described below:

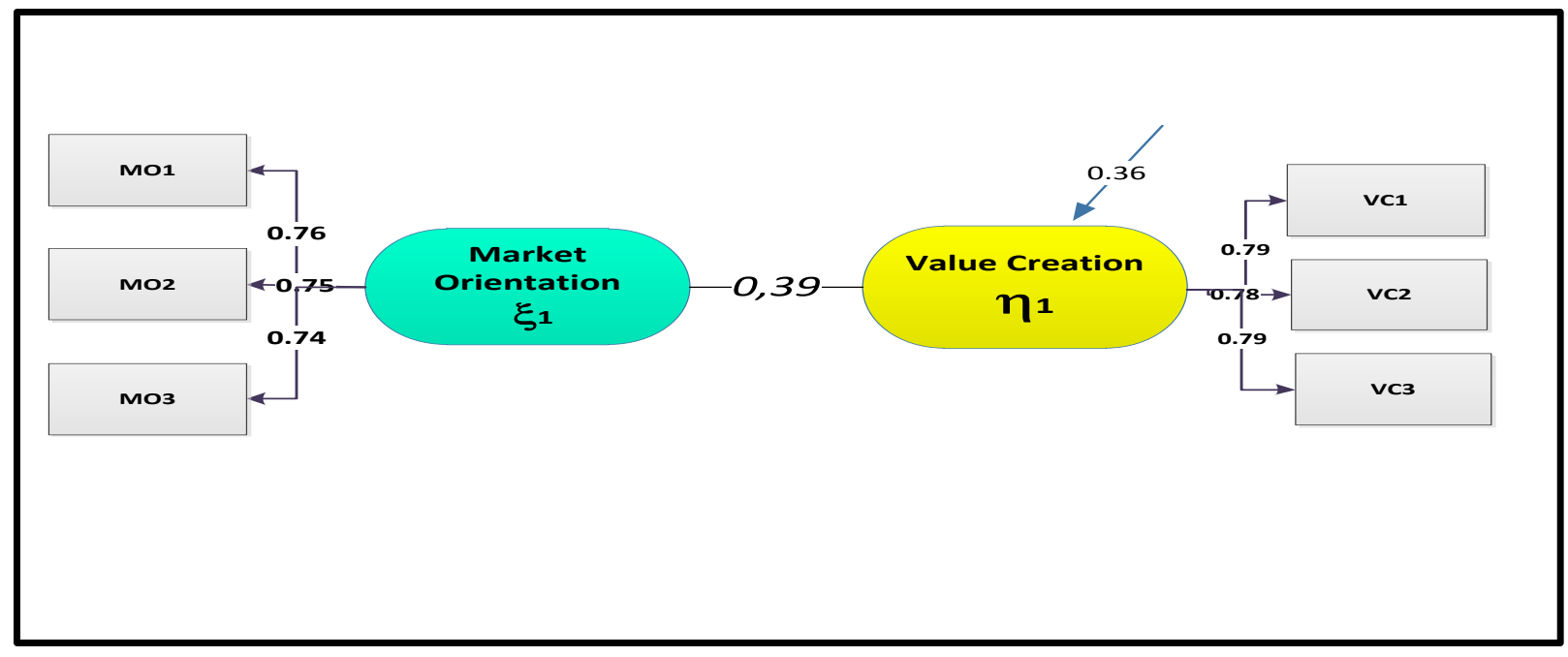

Source: data was processed, 2019

Figure 2 Market orientation affects partially value creation

In Figure 2, the results of the study show that market orientation consisting of customer orientation, competitor orientation, and coordination among functions, is one aspect that can affect medium value creation that is $22 \%$. Then Moslem fashion womenpreneurs are increasingly market-oriented, the more creative. The Moslem fashion womenpreneur are also generally able to keep up with the development of the current Moslem fashion trend, able to read the competitive situation, as well as internal communication within the company so that they are likely to increasingly have high creativity especially from creating unique designs and maintaining business partnerships.

For Moslem fashion womenpreneurs in the scale of small businesses in West Java, that market orientation has a role in the process of value creation or value creation. As revealed in his research Mauludin, et al (2013) that the implementation of market orientation in business will play a role in value creation. The essence of value creation itself is the comparison between the value of the benefits of sacrifice. It is not an easy task for Moslem fashion womenpreneurs to be 
able to realize the concept of value creation. However, with a good understanding of market orientation and how the state of the market will be producing information about customers about customer desires for the Moslem fashion model, Moslem fashion trends, satisfaction of meeting customer needs, how products are suited to customer tastes, product excellence, understand changes in customer needs and wants, and understand the level of purchasing power of customers.

Information about its competitors through the ability to read the Moslem fashion competition situation, observe the Moslem fashion competition situation, identify the strengths and weaknesses of the Moslem fashion competitor, identify the objectives to be achieved by competitors, identify areas or customer groups controlled by Moslem fashion competitors, and identify the strengths of the way marketing Moslem fashion products made bypassing. Moslem fashion womenpreneurs will coordinate with their employees in terms of discussing Moslem fashion products needed by customers, formal interaction in discussing strategies implemented in the company, discussing potential Moslem fashion customers, and disseminating information to all employees about market developments. So thus the of Moslem fashion womenpreneurs based on this will be able to design a value creation program or value creation of their products more effectively.

\section{Innovation affects partially value creation}

The effect of innovation on value creation can be seen in the results described in table 3 below:

Table 4 Market orientation affects partially value creation

\begin{tabular}{|c|c|c|c|c|c|}
\hline Hypothesis & $\boldsymbol{\gamma}$ & $\mathbf{S E}(\boldsymbol{\gamma})$ & $\mathbf{t}_{\text {count }}$ & $\mathbf{R}^{2}$ & Conclusion \\
\hline $\begin{array}{c}\text { Innovation } \rightarrow \text { Value } \\
\text { Creation }\end{array}$ & 0.59 & 0.075 & $7.85^{*}$ & 0.42 & $\begin{array}{c}\text { Hypothesis } \\
\text { Accepted }\end{array}$ \\
\hline
\end{tabular}

* significant at $\alpha=0.05(\mathrm{t}$ table $=1.98)$

Source: data was processed, 2019

In table 4 above, as we have known that the innovation variable has a strong enough influence on the value creation where $t_{\text {count }}>t_{\text {table }}$ with a coefficient of determination $R 2$ of $42 \%$. The illustrated that the contribution influence of innovation in forming a strong value creation that is equal to $42 \%$. Innovation consists of three factors, namely product innovation, process innovation, and marketing innovation, while value creation consists of benefits for customers, business uniqueness and business partnerships. For more details can be described below:

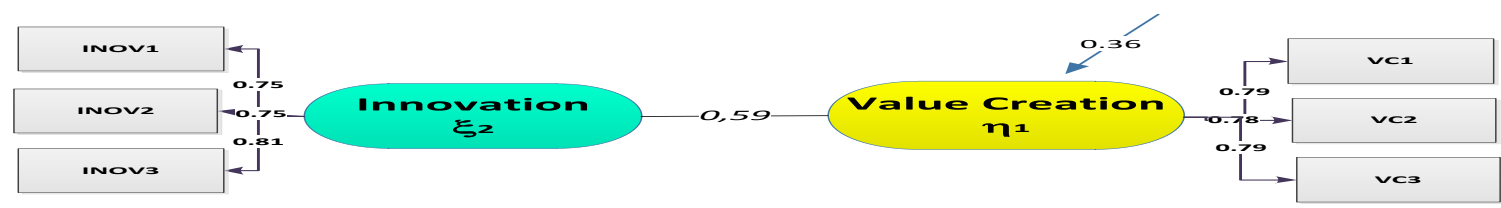

Source: data was processed, 2019

Figure 3 Market orientation affects partially value creation 
Figure 3 was the result of this research shows that innovation is one aspect that can affect value creation, by $42 \%$. When compared with the magnitude of the effect between market orientation on value creation, this study shows that the effect of innovation on value creation is stronger. So, in this case, Moslem fashion womenpreneurs are increasingly innovative in determining their products, processes, and marketing, they are more creative in providing useful products while highlighting the uniqueness of their business and also maintaining their business partnerships.

Sánchez-Gutiérrez, et al (2019), revealed in his research one of the factors that could be shaped customer value creation is marketing innovation so that it will later influence market competition. In realizing value creation for customers, Moslem fashion womenpreneurs in the small business scale in West Java need to carry out an innovation process that continues to be carried out primarily from product innovation in terms of following the Moslem fashion trend, material quality, and product design, then process innovation in terms of development the production process, the application of new technology, improvement in output quality, production costs, and marketing innovations in terms of product promotion updates, distribution channel systems, pricing techniques, following the Moslem fashion fair event, because innovation is a milestone in value creation as revealed by Špaček and Vacík (2016), that the company's ability to innovate is considered the most powerful value driver.

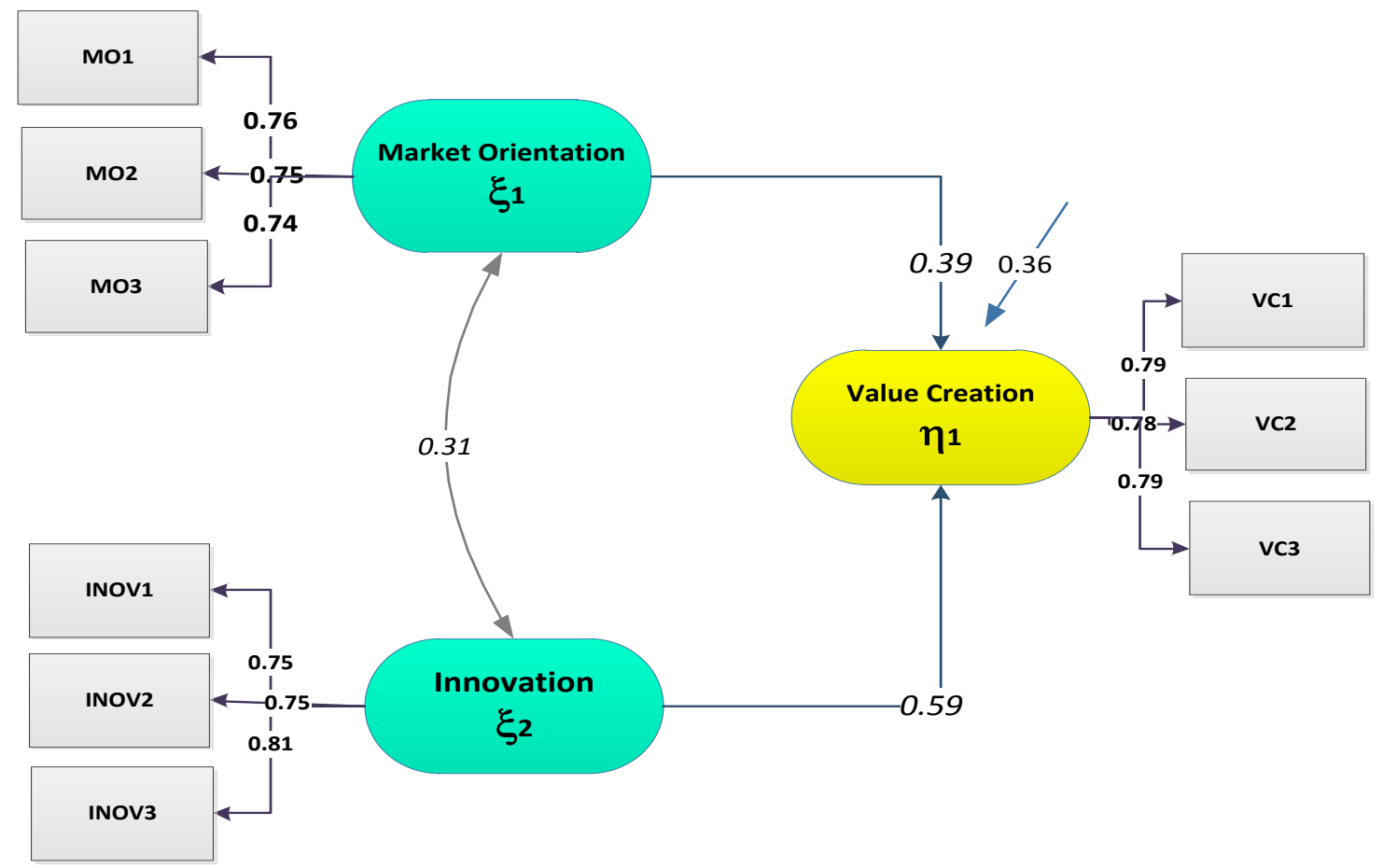

Source : data was processed, 2019

Figure 4. The Effect of Market Orientation and Innovation on Value Creation

Based on Figure 4 above, we can saw the following structural equation model :

$$
\eta_{1}=0.39 \xi_{1}+0.59 \xi_{2}+\zeta_{1}
$$


Note :

$$
\begin{aligned}
& \eta_{1}=\text { Value Creation } \\
& \xi_{1}=\text { Market Orientation }
\end{aligned}
$$

$$
\begin{aligned}
& \xi_{2}=\text { Innovation } \\
& \zeta \mathrm{i}=\text { Residual }
\end{aligned}
$$

Furthermore, to examine the effect of jointly - market orientation and innovation on value creation, statistically can be seen in the following table:

Table 4 The Effect of Market Orientation and Innovation on Value Creation

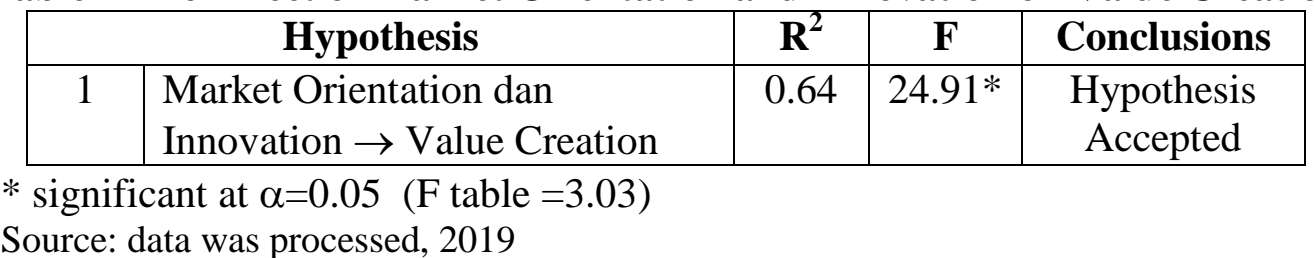

The results of the calculation of the influence of market orientation and innovation on value creation in table 4 above, it is known that simultaneous Market Orientation and Innovation variables have a significant effect on value creation where $F$ arithmetic $>F$ table with a coefficient of determination R2 of $64 \%$. Where the $64 \%$ is obtained from the sum of the coefficient of determination between the effect of market orientation on value creation and innovation on value creation. The effect of market orientation and innovation examining on value creation, it could be interpreted that simultaneously market orientation and innovation have a significant effect on value creation, which contributes a strong influence of $64 \%$ to value creation.

Womenpreneurs are increasingly oriented to the market formed through customer orientation, competitor orientation, and inter-function coordination and increasingly innovative in terms of product innovation, process innovation, and marketing innovation, it will be more creative in providing benefits to customers, highlighting the uniqueness of the business and maintaining business partnerships.

The results of this research also showed that market orientation and innovation are important factors in the formation of value creation or value creation for women Moslem fashion entrepreneurs of small scale businesses in West Java. As revealed by Ansari and Dehghanan (2015) in their research that innovation here not only adjusts the relationship between market orientation and entrepreneurship but also adjusts the relationship between market orientation and value creation for customers, it can be said market orientation and innovation have a significantgood effect it is towards entrepreneurship as well as value creation or value creation. However, if we look at the effect of market orientation and innovation on value creation partially, we can see how the influence of market orientation on value creation and the effect of innovation on value creation.

\section{CONCLUSION AND SUGGESTIONS}

Based on the quantitative research through the method of questionnaire distribution Market Orientation and Innovation have a strong influence on value creation in Moslem fashion womenpreneurs in West Java. This means that the more market-oriented and the more innovative the innovation, the more creative it will be in creating the value of the product. But innovation 
has a stronger direct effect on value creation when compared to the direct influence of market orientation on value creation.

Then it can be suggested for Moslem fashion womenpreneurs, should be more willing to explore the desires of consumers, more focused on the ability to identify the goals to be achieved by competitors. and the ability of Innovation to better identify areas or customer groups controlled by competitors. to further explore the ability to be able to reduce production costs which generally they experience difficulties, as well as more intense participation in fair events, especially Moslem fashion. Furthermore, more focused on exploring the ability to create fashion designs that are different from competitors, and need to be more actively involved in fashion organizations, especially fashion Moslem.

But for policymakers namely the West Java KUKM Office and West Java IPEMI, to collaborate to be more proactive to invite Moslem fashion womenpreneurs to be actively involved in the community and increase the frequency of coaching through training to explore the potential of reading markets and the ability to innovate by highlighting the uniqueness design of Moslem fashion products. The uniqueness of these products can later be promoted through social media to achieve productive business performance for Moslem fashion womenpreneurs.

\section{REFERENCE}

Alshammaria, Abdul Sattar Almujaiheem., Raslia, Amran., Mustaffaa, Nik Zahirah Nik, and Alnajemb, Majeedah. 2014. Organizational Innovation and Value Creation in Small Technology-based Companies in Malaysia. Jurnal Teknologi. Penerbit UTM Press. All rights reserved.

Amit, Raphael and Zott, Christoph. 2001.Value Creation In E-Business. Strategic Management Journal. Strat. Mgmt. J., 22: 493-520 (2001). DOI: 10.1002/smj.187.

Ansari, Tooba \& Dehghanan, Hamed. 2015. Impact of Market Orientation and Innovation on Entrepreneurship and Value Creation for Customers in Food Industry' SMEs. International Journal of Agricultural Management and Development (IJAMAD) Available online on: www.ijamad.iaurasht.ac.ir. ISSN: 2159-5852 (Print). ISSN:21595860 (Online).

Banjarmasin Post, 2014. Perancang Busana Moslem di Indonesia Paling Banyak di Jawa Barat. Minggu, 14 September 2014. (online) www.banjarmasinpost.co.id diakses pada tanggal [April 19, 2017].

Bjerke, B. and Hultman, C.M. 2002. Entrepreneurial Marketing - The Growth of Small Firms in the New Economic Era. Cheltenham/Northampton, MA, Edward Elgar.

Becherer, R.C., Haynes, P.J. and Fletcher, L.P. 2006. Paths to profitability in owner-operated firms: the role of entrepreneurial. Journal of Business and Entrepreneurship, 18(1), 1731.

Becherer, R. C., Haynes, P. J., and Helms, M. M. 2008. An Exploratory Investigation of Entrepreneurial Marketing in SMEs: The Influence of Owner/Operator. Journal of Business and Entrepreneurship, 20(2), 44-63.

Cravens, David W, and Piercy, Nigel F, 2014, Strategic Marketing. McGraw-Hill International $9^{\text {th }}$ Edition. New York: The McGraw-Hill Companies, Inc. Page 15.

Chung, Yi-Yung. 2015. Exploring a Missing Link for the Market Orientation Effect on Business Performance: The Strategic Role of Customer Value Creation Capabilities. Journal of Management 2015, Vol. 32, No. 3, 247-292. DOI: 10.6504/JOM.2015.32.03.02. 
Das, Mallika. 2000. Men and Women in Indian Magazine Advertisements: A Preliminary Report. Sex Roles A Journal Of Research, November 2000, Volume 43(9), pp 699-717.

De Vita, Luisa., Mari, Michela., Poggesi, Sara. 2013. Women entrepreneurs in and from developing countries: Evidences from the literature. European Management Journal, http://dx.doi.org/10.1016/j.emj.2013.07.009

Dinas Koperasi dan Usaha Kecil Menengah (KUKM) Provinsi Jawa Barat, 2016. Penanggung Jawab Ketua Dinas KUKM Provinsi Jawa Barat 2016.

Grönroos, Christian. 2011. A service perspective on business relationships: The value creation, interaction, and marketing interface. Industrial Marketing Management 40 (2011) 240247

Hacioglu, G., Eren, S., Eren, M. and Celikkan, H. 2012. The effect of entrepreneurial marketing on firms' innovative performance in Turkish SMEs. Procedia - Social and Behavioural Sciences, 58, 871-878.

Haryanto, A.T, and Haryono. T. 2015. The Influence Of Market Orientation On Innovation Type And Enterprise Performance. Polish Journal Of Management Studies. Vol.11 No1. pp 68 $-78$.

Hills, G.E., Hultman, C.E., Kraus, S., and Schulte, R. 2010. History, theory, and evidence of entrepreneurial marketing - an overview. International Journal of Entrepreneurship and Innovation Management, 11(1), pp $3-8$.

Indiworo, Hawik Ervina. 2016. Peran Perempuan Dalam Meningkatkan Kinerja UMKM. Jurnal Equilibria Pendidikan Vol. 1, No. 1, 2016

IONIŢĂ, Daniela. 2012. Entrepreneurial Marketing: A New Approach For Challenging Times. Management and Marketing Challenges for the Knowledge Society. 7(1), pp. $131-150$.

Jime'nez-Zarco, et al. 2011. The impact of market orientation dimensions on client cooperation in the development of new service innovations. European Journal of Marketing. Vol. 45 No. 1/2, 2011. pp. 43-67. Emerald Group Publishing Limited.

Johansson, Niklas, and Mollsted, Ulrika. 2006. Revisiting Amit and Zott's model of value creation sources: The SymBelt Customer Center case. Journal of Theoretical and Applied Electronic Commerce Research. ISSN 0718-1876 Electronic Version. Vol 1 / Issue 3 / December 2006 / 16 - 27

Jones, Rosalind, and Rowley, Jennifer. 2011. Entrepreneurial marketing in small businesses: A conceptual exploration. International Business Journal (sage Publications), 29, 25-36

Karwati, Lilis., Ansori, and Mulyono, Dinno. 2018. Women Empowerment to Build Entrepreneurship. Journal of Nonformal Education. JNE 4 (2) (2018). DOI: http://dx.doi.org/10.15294/jne.v4i2.16005.

Kemp, R.G.M., Folkeringa, M., Jong, de J.P.J., Wubben, E.F.M. 2003. Innovation and firm performance. Research Report. Zoetermeer. SCALES. Scientific Analysis of Entrepreneurship and SMEs. Pp 31 - 53.

Kotler, Philips, and Keller Kevin Lane. 2016. Marketing Management. 15e. Global Edition. New Jersey: Pearson Edition, Inc.

Lia Yuldinawati. 2015. Jumlah Pengusaha UMKM Perempuan Meningkat. July 13, 2015, 20:59 WIB (online). www.republika.co.id [Accessed January 9, 2016]

Li, Yuan., Zhao, Yongbin., Tan, Justin., Yiu, Li. 2008. Moderating Effect Entrepreneurial Orientation on Market Orientation-Performance Linkage: Evidence from Chinese Small Firms. Journal of Small Business Management 46(1), pp. 113 - 133. 
Kraus, S., Harms, R. and ink, M. 2010. Entrepreneurial marketing: moving beyond marketing in new ventures. Int. J. Entrepreneurship and Innovation Management, 11(1), 19 - 34.

Mauludin, Hanif., Alhabsji, Taher., Idrus, Syafii., Arifin, Zainul. 2013. Market Orientation, Learning Organization, and Dynamic Capability as Antecedents of Value Creation. IOSR Journal of Business and Management (IOSR-JBM). e-ISSN: 2278-487X, p-ISSN: 23197668. Volume 10, Issue 2 (May. - Jun. 2013), PP 38-48.

McNaughton, Rod B., Osborne, Phil., C. Imrie, Brian. 2002. Market-oriented value creation in service firms, European Journal of Marketing, Vol. 36 Issue: 9/10, pp.990-1002, https://doi.org/10.1108/03090560210437299

Miles, M.P. and Darroch, J. 2004. Large Firms, Entrepreneurial Marketing Processes and The Cycle of Competitive Advantage. European Journal of Marketing, 40(5/6), 485-501.

Morris, M.H. and Paul, G.W. 1987. The Relationship Between Entrepreneurship and Marketing in Established Firms. Journal of Business Venturing, Elsevier Science Publishing, 2(3), 247-259

Morris, M.H., Schindehutte, Minet, and LaForge, R.W. 2002. Entrepreneurial Marketing: A Construct for Integrating Emerging Entrepreneurship and Marketing Perspective. Journal of Marketing Theory and Practice, 1-19.

O'Cass, Aron and Sok, Pyra. 2012. Exploring innovation-driven value creation in B2B service firms: The roles of the manager, employees, and customers in value creation. Journal of Business Research xxx (2012) xxx-xxx.

Oslo Manual. 2005. Guidelines For Collecting And Interpreting Innovation Data. Third edition. Organization For Economic Co-Operation And Development Statistical Office Of The European Communities. Pp. 27 - 59.

Peters, Linda D. 1997. IT-enabled marketing: a framework for value creation in customer relationships, Journal of Marketing Practice: Applied Marketing Science, Vol. 3 Iss 4 pp. $213-229$.

Ramli, Yanto., and Shelton, Mochamad. 2018. Implementing Innovation Management on Market Attractiveness and Unique Resources To Enhance Business Performance on Organic Fertilizer Industries In Indonesia. Academy of Strategic Management Journal. Volume 17, Issue 2, 2018, pp $1-12$.

Rosmayani., Suryana, Yuyus., Suwawihardja, Surachman and Helmi, R. Arief. 2016. Influence Of Market Orientation And Innovation On Marketing Performance In Small Industry Of Malay Woven Textile, Riau Province, Indonesia. International Journal of Economics, Commerce, and Management. United Kingdom Vol. IV, Issue 2, February 2016. Licensed under Creative Common Page 521 - 536. http://ijecm.co.uk/ ISSN 23480386.

Sánchez-Gutiérrez, José., Cabanillas, Pablo., Lampón, Jesús F., González-Alvarado, Tania E., (2019) "The impact on the competitiveness of customer value creation through relationship capabilities and marketing innovation", Journal of Business \& Industrial Marketing, Vol. 34 Issue: 3, pp.618-627, https://doi.org/10.1108/JBIM-03-2017-0081

Safira Primadhyta. 2015. Apindo: Perempuan Harus Tingkatkan Peran di Sektor Ekonomi. CNN Indonesia Selasa, 24/02/2015 20:15 WIB (online). www.cnnindonesia.com [accessed on January 9, 2016].

Slater, Stanley F, and Narver, John C. 2000. The Positive Effect of a Market Orientation on Business Profitability: A Balanced Replication. Journal of Business Research 48, 69-73 (2000). Elsevier Science Inc. All rights reserved. 
Špaček, Miroslav \& Vacík, Emil (2016), "Company Value Creation through Effective Innovation Process Management". Journal of Innovation Management. JIM 4, (3) 65 78. HANDLE: http://hdl.handle.net/10216/86100

Tambunan, Tulus. 2012. Wanita Pengusaha UMKM di Indonesia: Motivasi dan Kendala. Published by LPFE Trisakti University. ISSN 2085-661X (9772085661018). (C) 2012 Center for Industry, SME and Business Competition Studies, Trisakti University.

Wang, Catherine L., and Ahmed, Pervaiz K. 2004. The development and validation of the organizational innovativeness construct using confirmatory factor analysis. European Journal of Innovation Management. Volume 7 • Number 4 • $2004 \bullet$ pp. 303-313. Emerald Group Publishing Limited $\bullet$ ISSN 1460-1060.

Zainul, Mohammad., Astuti, Endang Siti., Arifin, Zainul., and Utami, Hamidah Nayati. 2016. The Effect of Market Orientation toward Organizational Learning, Innovation, Competitive Advantage, and Corporate Performance (A Study at SME Sasirangan in South Kalimantan). Journal of Administrative Sciences and Policy Studies. June 2016, Vol. 4, No. 1, pp. 1-19. Published by the American Research Institute for Policy Development. DOI: 10.15640/jasps.v4n1a1. URL: https://doi.org/10.15640/jasps.v4n1a1 